\title{
Environmental management of pesticidal POPs in China: Past, present and future
}

\author{
Dongbin Wei ${ }^{a, b, *}$, Takashi Kameya ${ }^{b}$, Kohei Urano ${ }^{b}$ \\ ${ }^{\mathrm{a}}$ Research Center for Eco-Environmental Sciences, Chinese Academy of Sciences, Beijing 100085, PR China \\ ${ }^{\mathrm{b}}$ Graduate School of Environment and Information Sciences, Yokohama National University, Yokohama 240-8501, Japan
}

Received 25 September 2006; accepted 17 April 2007

Available online 22 May 2007

\begin{abstract}
China, the largest developing country in the world, has been undergoing rapid economic growth in the past two decades. Synchronously, large quantities of persistent organic chlorinated pesticides have been used in agriculture and non-agriculture areas. Accompanying with incomplete management framework, the improper use and disposal of pesticides have caused serious pollution problems. In this study, we discussed: (1) ten persistent organochlorine pesticides in terms of historical production, consumption and number of manufacturers, import and export; (2) the current management framework of pesticidal persistent organic pollutants (POPs) with respect to legal system and government administrative system; (3) the existing problems in the management of pesticidal POPs; and proposed recommendations for countermeasures. Based on the available information, it can be concluded that records on the historical production and consumption quantities of pesticidal POPs are incomplete which makes a difficulty in the management. Although China has come a long way in developing a modern legal system, the current system is still considered weak and inefficient; and many challenges are ahead. The government administrative system has also been reformed and improved, but over-lapping jurisdictions still exist and are ineffective in managing pesticidal POPs program. To address these existing problems in pesticidal POPs management, it was suggested that more investigations should be conducted to collect information on pollution sources of pesticidal POPs, to evaluate their environmental risks, to identify new alternative chemicals and to complete management framework of pesticidal POPs in China. Furthermore, the public should be encouraged to participate in managing hazardous pesticidal POPs in China, and international cooperation and communication should be established and strengthened imperatively as well.
\end{abstract}

(C) 2007 Elsevier Ltd. All rights reserved.

Keywords: Pesticidal POPs; Pollution source; Management framework; China

\section{Introduction}

A dozen "dirty" organochlorinated substances are listed as persistent organic pollutants (POPs) by the United Nations Environment Program (UNEP) in the 1995 Stockholm Convention. Hazards associated with POPs substances include their persistence in the environment, bioaccumulation potential in the tissues of organisms through food chain, and toxicities for human and wildlife. Moreover, POPs may also be transported for long-range by air, rivers and ocean currents, and contaminate regions far from their sources. For international cross-boundary pollution problems, there is a need for international cooperation

\footnotetext{
* Corresponding author. Research Center for Eco-Environmental Sciences, Chinese Academy of Sciences, Beijing 100085, PR China.

E-mail address: weidb@rcees.ac.cn (D. Wei).
}

and efforts (Tanabe, 1991; Wania and Mackay, 1996). Phase-out and control of pesticidal POPs is one of the predominant facets in implementing Stockholm Convention.

Of the 12 POPs substances, nine are pesticides (aldrin, endrin, dieldrin, heptachlor, chlordane, mires, toxaphene, DDT and hexachlorobenzene (HCB)). Since hexachlorocyclohexane $(\mathrm{HCH})$ is one of POPs candidates that have been produced and used heavily in China, in this study, the term "pesticidal POPs" includes HCH. It was noted that during 1950s-1970s, the organochlorine pesticides (such as DDT, $\mathrm{HCH}$ ) accounted for about $80 \%$ of the total pesticides produced. As a major agricultural country, China increased total grain output from 110 million tons in 1949 to 470 million tons in 2004 (NBSC, 2005), which partly attributed to the heavy usage of chemical fertilizers and pesticides. The pesticides consumption quantity was about $260 \mathrm{kt}$ of active ingredients in 2004 (SEPA, 2005). 
Although agricultural use of most pesticidal POPs have been banned in China for more than 20 years, the pollution investigation and pesticide management are much complicated in China due to many factors including: incomplete statistics data, over-application of pesticides, persistence characteristics of pesticides, production exemption (e.g. DDT, chlordane, mirex and $\mathrm{HCB}$ ) for limited usages, incomplete management framework (Huang, 1989; Qiu et al., 2005; Fu et al., 2003; Zhang, 1996; Chen et al., 2005; Loganathan and Kannan, 1994). Therefore, the purpose of this study was: (1) to explore the potential pollution sources of pesticidal POPs such as production and consumption information, (2) to summarize the management framework on pesticidal POPs, and (3) to propose countermeasures for the control and management of pesticidal POPs in China.

\section{Potential pollution sources of pesticidal POPs in China}

All the information about the production, consumption, manufactures of ten pesticidal POPs are summarized in Table 1. It can be seen that seven out of ten pesticidal POPs (DDT, HCH, toxaphene, $\mathrm{HCB}$, chlordane, heptachlor and mirex) were produced at an industrial scale in China, and the other three (aldrin, dieldrin and endrin) were produced, only at a pilot plant level, or in research phase during 1950s to 1980s (Cheng, 2001). After 1982, with the implementation of the Pesticides Register System in China, the production and agricultural usage of six pesticidal POPs ( $\mathrm{HCH}$, toxaphene, heptachlor, aldrin, dieldrin and endrin) were banned completely. However, under the exemption in Stockholm Convention, HCB and three other pesticides: DDT, chlordane and mirex are still in production with limited use in China.

\section{1. $D D T$}

DDT was firstly synthesized in 1874 , but its insecticidal properties remained unknown until 1939. The data on the quantities of DDT produced/used in China, India, Japan, and USA are summarized in Table 2. It can be seen that India is the largest producer/user of DDT in the world, followed by China. However, considering the arable land, Japan consumed the largest average amount of DDT per unit of arable land, $0.26 \mathrm{~kg} /$ kha/year, and about $0.1 \mathrm{~kg} / \mathrm{kha} /$ year in China (Li et al., 1998a).

Table 1

Production, consumption, ban and exemption of Pesticidal POPs in China

\begin{tabular}{|c|c|c|c|c|c|c|c|c|c|c|}
\hline \multirow[t]{2}{*}{ Category } & \multirow[t]{2}{*}{$\begin{array}{l}\text { Production } \\
\text { quantity }\end{array}$} & \multirow[t]{2}{*}{$\begin{array}{l}\text { Consumption } \\
\text { quantity }\end{array}$} & \multirow[t]{2}{*}{ Import/export } & \multicolumn{2}{|c|}{$\begin{array}{l}\text { No. of } \\
\text { plants }\end{array}$} & \multirow[t]{2}{*}{$\begin{array}{l}\text { Started } \\
\text { year }\end{array}$} & \multicolumn{2}{|c|}{ Banned year } & \multirow[t]{2}{*}{ References } & \multirow[t]{2}{*}{ Remarks } \\
\hline & & & & Past & Now & & Agri. & All & & \\
\hline \multirow[t]{3}{*}{ DDT } & $\begin{array}{l}15 \mathrm{kt} / \mathrm{y} \\
(1970 \mathrm{~s}-1983) \\
2-3 \mathrm{kt} / \mathrm{y} \\
(1995-2000)\end{array}$ & $\begin{array}{l}1.9 \mathrm{kt} / \mathrm{y}(1970 \mathrm{~s}) \\
3-4.5 \mathrm{kt} / \mathrm{y} \text { (current) }\end{array}$ & $\begin{array}{l}\text { Imp. } 20 \mathrm{t} \\
(1991)\end{array}$ & 11 & 2 & 1951 & 1983 & In use & UNIDO (2003) & $\begin{array}{l}\text { Stock of discofol; } \\
\text { disease vector; } \\
\text { export }\end{array}$ \\
\hline & $\begin{array}{l}4-6 \mathrm{kt} / \mathrm{y} \\
\text { (current) }\end{array}$ & & $\begin{array}{l}\text { Exp. } 0.1-1 \mathrm{kt} \\
\text { (current) }\end{array}$ & & & & & & UNEP (2002) & \\
\hline & $\begin{array}{l}430 \mathrm{kt} \\
(1951-1983)\end{array}$ & 430 kt (1951-1983) & & & & & & & Li et al. (1998c) & \\
\hline $\mathrm{HCB}$ & $\begin{array}{l}\text { Max } 7365 \mathrm{t} / \mathrm{y} \\
(1990) \\
3522 \mathrm{t} / \mathrm{y}(2003) \\
\text { Total: } 300 \mathrm{kt}\end{array}$ & - & - & 6 & 1 & 1945 & - & In use & UNEP (2002) & $\begin{array}{l}\text { Chemical mediate of PCP; } \\
\text { dissolvent; chemical assistant; } \\
\text { soil fumigant }\end{array}$ \\
\hline Chlordane & $\begin{array}{l}160 \mathrm{t} / \mathrm{y}(1998) \\
\text { Max } 843 \mathrm{t} / \mathrm{y} \\
(1999) \\
450 \mathrm{t} / \mathrm{y}(2003) \\
\text { Total: } 3 \mathrm{kt}\end{array}$ & 130 or $200 \mathrm{t} / \mathrm{y}$ & Exp. $30 \mathrm{t}$ & 13 & 2 & 1945 & 1999 & In use & World Bank (2005) & Termite prevention \\
\hline Mirex & $\begin{array}{l}\text { Max } 31 \mathrm{t} / \mathrm{y} \\
(2000) \\
9 \mathrm{t} / \mathrm{y}(2003) \\
93.8 \mathrm{t} \\
(1997-2002)\end{array}$ & $0.3 \mathrm{t} / \mathrm{y}$ & - & 8 & 3 & 1958 & - & In use & World Bank (2005) & Termite prevention \\
\hline Toxaphene & $\begin{array}{l}\operatorname{Max} 3740 \mathrm{t} / \mathrm{y} \\
(1973) \\
24 \mathrm{kt}(1964-1980)\end{array}$ & 0 & - & 16 & 0 & 1948 & - & 1982 & $\begin{array}{l}\text { UNEP (2002) } \\
\text { UNIDO (2003) }\end{array}$ & \\
\hline Heptachlor & $\begin{array}{l}1.0 \mathrm{t} / \mathrm{y}(1969) \\
\text { Total: } 17 \mathrm{t}\end{array}$ & - & - & 8 & 0 & 1948 & - & 1982 & $\begin{array}{l}\text { UNEP (2002) } \\
\text { UNIDO (2003) }\end{array}$ & \\
\hline Aldrin & 0 & - & - & 3 & 0 & - & - & 1983 & $\begin{array}{l}\text { UNEP (2002) } \\
\text { UNIDO (2003) }\end{array}$ & \\
\hline Dieldrin & 0 & - & - & 0 & 0 & - & - & 1983 & $\begin{array}{l}\text { UNEP (2002) } \\
\text { UNIDO (2003) }\end{array}$ & \\
\hline Endrin & 0 & 0 & - & 2 & 0 & - & - & 1983 & $\begin{array}{l}\text { UNEP (2002) } \\
\text { UNIDO (2003) }\end{array}$ & \\
\hline $\mathrm{HCH}$ & $\begin{array}{l}4460 \mathrm{kt} \\
(1952-1983)\end{array}$ & 4460 kt (1952-1983) & - & - & - & 1952 & - & 1983 & $\begin{array}{l}\text { Li et al. (1998a) } \\
\text { Li et al. (1998b) }\end{array}$ & \\
\hline
\end{tabular}


Table 2

Total DDT production/usage for China, India, Japan and USA

\begin{tabular}{llllll}
\hline Country & $\begin{array}{l}\text { Production } \\
\text { years }\end{array}$ & $\begin{array}{l}\text { Production } \\
(\mathrm{kt})\end{array}$ & Usage years & $\begin{array}{l}\text { Usage } \\
(\mathrm{kt})\end{array}$ & References \\
\hline China & $1951-1983$ & 270 & $1951-1983$ & 270 & Li et al. (1998c) \\
India & $1948-1989$ & 330 & $?$ & 330 & PANNA (1990) \\
Japan & $1957-1970$ & 30 & $1948-1971$ & 30 & $\begin{array}{l}\text { Loganathan et al. } \\
\text { (1989) }\end{array}$ \\
USA & $1945-1970$ & 1300 & $1939-1973$ & 590 & USEPA (1975) \\
\hline
\end{tabular}

It was estimated that total consumption of commercial DDT in the world was about 2.6 million tons from 1950 to 1993 (Voldner and Li, 1995), especially, from 1981 to 1984, about $311 \mathrm{kt}$ of DDT was consumed in 103 countries annually (Jones and Voogt, 1999).

China started the production and use of DDT from 1951, and the total production of commercial DDT was more than $430 \mathrm{kt}$ from 1951 to 1983 (Wong et al., 2002). The annual DDT production was plotted in Fig. 1(a). Historically, there were eleven DDT enterprises in China, however, only Tianjin Chemical Plant and Yangzhou Pesticidal Plant are still in production and their annual production quantity is 4-6 kt (UNIDO, 2003).

In China, DDT was mainly used in agriculture for controlling army worm, ball worm, pink ball worm, apple tortrix moth, greenish brown hawk moth on wheat, maize, cotton, orchard, soybean and sorghum (Cai et al., 1992). The consumption percentages of DDT on various crops in 1980 were, about $65 \%$ on cotton, $15 \%$ on soybean and sorghum, $10 \%$ on wheat and $10 \%$ on maize (Cai et al., 1992). The agricultural use of DDT was banned in 1983 (Cheng, 1990), while at present, under the exemption of Stockholm Convention, only a relatively small quantity of DDT can be used for: 1) stock of dicofol, 2) disease vector control, 3) export, and 4) producing mosquito-repellent incense and special paint.

Because of insufficient DDT production capacity, about $20 \mathrm{t}$ DDT was imported in 1991. Import of DDT has been banned since 1994 because DDT is listed in Ordinance of the Environmental Management on the First Import of Chemicals and the Import/Export of Toxic Chemicals (http://www.crc-
sepa.org.cn/English/e021.htm). One of the main purposes of DDT production in China is to export for disease vector control in the tropical regions where malaria breaks out heavily such as Southeast Asia and Africa. The export of DDT is about $300 \mathrm{t} /$ year (including some HCB) since 1995 (UNIDO, 2003).

\subsection{Technical $\mathrm{HCH}$}

Technical HCH, as a broad-spectrum insecticide, has been produced and used in the world for both agricultural and nonagricultural purposes due to its effectiveness and low cost. It was estimated that total consumption of technical HCH in the world was about 9.7 million tons from 1948 to 1997 (Li, 1999a), Most developed nations banned the use of technical $\mathrm{HCH}$ in the 1970s, but it was not banned in developing countries until 1980s due to diseases vector control (Volder and Li, 1995; Igbedioh, 1991).

China started to produce and use technical $\mathrm{HCH}$ in 1952, and the total amount of technical $\mathrm{HCH}$ produced in China was 4.5 million tons before its use was banned in 1983 ( $\mathrm{Li}$ et al., $1998 \mathrm{~b}$ ), which accounted for about $30 \%$ of total world production. Annual production of technical $\mathrm{HCH}$ is depicted in Fig. 1(b) which shows the production increased yearly, and reached a peak in 1972. After decreasing for a few years, production increased again and reached a second peak in 1980, then decreased to zero in 1984.

In China, technical $\mathrm{HCH}$ was mainly used in agriculture, although a small portion was used in forestry and public health (Cai et al., 1992). Crops on which $\mathrm{HCH}$ was widely used in China were rice, wheat, maize, cotton, soybean, sorghum, orchards and some vegetables to attack a wide variety of pests for different crops. Among them, more than half of $\mathrm{HCH}$ was used in rice paddies, $25 \%$ on wheat, and $10 \%$ on each of soybean/sorghum and maize. The most intense use of technical HCH was on orchard, but it constituted only $1.4 \%$ of total consumption in 1980 due to small percentage of orchard acreage (Cai et al., 1992).

The amount of technical $\mathrm{HCH}$ produced/used in China, India, Japan, and USA is summarized in Table 3 which shows that China was the biggest producer/user of technical $\mathrm{HCH}$ in
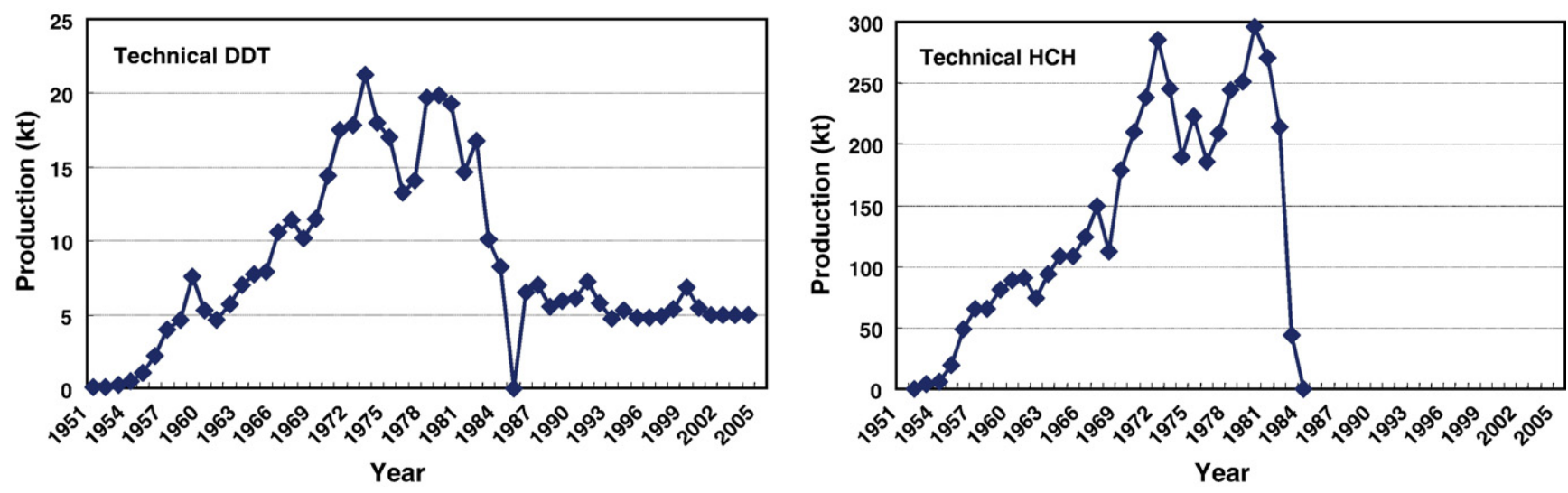

Fig. 1. History production of commercial DDT and technical $\mathrm{HCH}$ in China. 
Table 3

Total technical HCH production/usage for China, India, Japan and USA

\begin{tabular}{|c|c|c|c|c|c|}
\hline Country & $\begin{array}{l}\text { Production } \\
\text { years }\end{array}$ & $\begin{array}{l}\text { Production } \\
(\mathrm{kt})\end{array}$ & $\begin{array}{l}\text { Usage } \\
\text { years }\end{array}$ & $\begin{array}{l}\text { Usage } \\
(\mathrm{kt})\end{array}$ & References \\
\hline China & $1952-1983$ & 4900 & $\begin{array}{l}1952- \\
1983\end{array}$ & 4,460 & Li et al. (1998b) \\
\hline India & $1948-1995$ & 1000 & $?$ & 1,000 & Kannan et al. (1995) \\
\hline Japan & $1950-1970$ & 400 & $\begin{array}{l}1948- \\
1972\end{array}$ & 400 & $\begin{array}{l}\text { Loganathan et al. (1989); } \\
\text { Tatsukawa et al. (1972) }\end{array}$ \\
\hline USA & $1947-1963$ & 350 & $\begin{array}{l}1947- \\
1976\end{array}$ & 350 & $\begin{array}{l}\text { Rapaport and Eisenreich } \\
\text { (1988); USEPA (1980) }\end{array}$ \\
\hline
\end{tabular}

the world, followed by India. However, when considering the arable land of each country, Japan has the highest usage density, about $3.7 \mathrm{t} / \mathrm{kha} /$ year, and China followed, about $1.3 \mathrm{t} / \mathrm{kha} / \mathrm{year}$ (Li et al., 1998b).

\subsection{Chlordane and mirex}

Both chlordane and mirex are produced and consumed in China as termiticides. China is one of the countries with the greatest diversity of termites and most severe termite damage in the world. About 482 species of termites are found in most area south of the Yangtze River in China, and have caused damages to between 30 and $90 \%$ of buildings south of the Yangtze River. It was estimated that the direct economic loss caused by termites in China was about 2 to 2.5 billion yuan annually (Xia and Dai, 2001).

Since the introduction of chlordane and mirex to China, they have become the principal instruments and have been widely used for termite prevention and control due to their effectiveness, persistence, low cost and ease of application. From 1995 to 2003 , about $5000 \mathrm{t}$ of chlordane and $140 \mathrm{t}$ of mirex were produced, especially, within 5 years from 1997 to 2001, $2300 \mathrm{t}$ of chlordane and $14 \mathrm{t}$ of mirex were used in China (WB, 2005).

After a series of laboratory tests and pilot production by seven research institutes and enterprises from 1957 to 1965 , fourteen enterprises started their commercial production of chlordane in 1970. During 1980 to 1987, five producers were closed completely, another three were stopped while their production facilities remained open, and six producers continued chlordane production with an output of 500 to $800 \mathrm{t} /$ year to December 2004 (Qin, 2004a).

China started the research of mirex in 1969, the Shanghai Electronchemical Plant tentatively produced mirex from 1970 until the production facility was dismantled in 1975. The produced mirex was either exported to Tanzania and Zambia for a government railroad project or sold to some other provinces of China. Thereafter, several manufacturers started to produce mirex around 1986, and there were five manufacturers with production facilities, only three remained with $30 \mathrm{t} / \mathrm{year}$ production and export by the end of 2004 (Qin, 2004a).

\subsection{Other pesticidal POPs}

Toxaphene and heptachlor, both were produced in industrial scale before the middle of 1980s in China. There were 16 toxaphene manufacturers, and the total production quantity was up to $3 \mathrm{kt}$ in 1970s. There were eight heptachlor manufacturers with total production quantity of about $1 \mathrm{t}$ in 1969 . However, these two chemicals have not been produced or consumed because they were banned in 1982. Toxaphene was broadly used for cotton pests, fruit trees pests and maize borer prevention. Heptachlor was mainly used for soil pests, termite and vector pests prevention.

HCB has never been used as pesticide in China, but as intermediate of $\mathrm{PCP}(-\mathrm{Na})$, dissolvent and assistant. The number of production enterprises of HCB was reduced from historical six to present one (another HCB plant has stopped its production but keeps producing equipments) with an estimated annual production quantity of about $2 \mathrm{kt}(\mathrm{Li}, 1999 \mathrm{~b})$. There is a slight possibility to import HCB because China has sufficient production capacity.

Aldrin, dieldrin and endrin have never been produced at large scale in China, and the research or trial production has been stopped. There are no import records for aldrin, dieldrin and endrin.

\section{Management framework of pesticidal POPs in China}

The management framework for pesticidal POPs in China is mainly composed of two systems. One is legal system, including: acts, regulations, ordinances, and criteria; and the other is the government administrative system, such as State Environmental Protection Administration, local environmental protection bureaus, public health department, agricultural department, and other departments, with responsibility for enforcing the acts.

\subsection{Legal system}

Since 1970s, Chinese government began to establish statutes for protecting environment and natural resources, and issued a series of acts, regulations, ordinances and criteria during the past three decades. However, there is no direct and special act for POPs control and management in China yet except for a few statutes.

\subsubsection{Development stages}

A review of the statutes and corresponding historic period indicated the legal system on pesticidal POPs management in China can be divided into three stages: disillusion and preparation stage (before 1982), extension stage (from 1982 to 1994), and rapid developing stage (after 1995).

In the first stage, Chinese government was aware of the serious environmental pollution situations, some acts related to environmental protection were adopted and issued, and began to prepare a plan for gradual phase-out of POPs in China. For example, the first national act on environmental protection in China, the Environmental Protection Act of People's Republic of China (for trial implementation) was adopted by the Standing Committee of the People's Congress in 1979. However, during the same period, some developed countries had already made progress on chemical management, e.g. Japan issued Chemical Substances Control Act in 1973, USA adopted Toxic Substances Control Act in 1976. 
In the second stage, Chinese government adopted additional national statutes on chemicals and signed several international conventions. National statutes include: Ordinance of Pesticide Registration (1982), Ordinance of Safety Use of Pesticide (1982), Regulation on Safety Administration of Dangerous Chemicals (1987), Water Pollution and Control Act (1984), Marine Environment Protection Act (1982), Air Pollution Prevention and Control Act (1988), amended the Environmental Protection Act of the People's Republic of China in 1989 after 10-year trial implementation. International conventions include: International Action Rule on the Sale and Use of Pesticide in 1989, London Guidelines in 1989 and Basel Convention in 1989, and 170 Convention in 1990. Compared with developed countries in this period, Japan and USA began to implement more detailed acts such as Agricultural Chemicals Regulations Law (Japan) in 1984 and amended the Toxic Substances Control Act (USA) in 1986, 1988, 1990 and 1992, respectively.

In the third stage, Chinese government signed most of the international conventions and treaties, adopted more specific and powerful national statutes, including: Rotterdam Convention (1998), Stockholm Convention (2001), and International Code of Conduct on the Distribution and Use of Pesticides (2003). Under these umbrellas, Chinese government is actively adopting some actions and implementing these conventions and treaties. In addition, Chinese government also adopted and amended tens of national statutes, such as Regulation on Management and Control of Chemicals (1995), Regulation on the Control of Agricultural Chemicals (1997), Regulations on the Control over Safety of Dangerous Chemicals (2002) and so on. It is expected to control and phase-out the pesticidal POPs in China in the near future.

\subsubsection{Category of statutes}

The national statutes related to pesticidal POPs management in China can be generalized into four facets: act, regulation, ordinance and criteria (Wang et al., 2005a). "Act" is usually adopted by the People's Congress and issued by the Chairman of China; "Regulation" is adopted by the State Department and issued by the Premier of China. "Ordinance" and "criteria" are adopted and issued by executive branches of the Chinese government Additionally, as mentioned above, Chinese government has also signed some international conventions and treaties for environmental protection chemical management, which are included in the legal system of China, along with those national acts, regulations, ordinances and criteria (DPLR/ SEPA, 2005).

There are seven acts in China concerning hazardous chemical management, i.e. Environmental Protection Act (1989), Labor Act (1995), Act on the Prevention and Control of Water Pollution (1996), Marine Environment Protection Act (1982), Act on the Prevention and Control of Atmospheric Pollution (2000), Act on the Prevention and Control of Environmental Pollution by Solid Waste (1996), Production Safety Act (2002). Under these national acts, pesticidal POPs are classified as both pesticides and hazardous chemicals, so there are two pathways to control pesticidal POPs substances and to ban their use. One pathway is for pesticide management, which includes one
Regulation (Regulations on the Control of Agricultural Chemicals, 1997), two Ordinances (Ordinance of Pesticide Registration, 1982; Ordinance of the Safe Use of Pesticide, 1982), and 10 Criteria. The other pathway is for management of hazardous chemicals and wastes, which include one Regulation (Regulations on the Control over Safety of Dangerous Chemicals, 2002), three Ordinances (Ordinance of the Environmental Management on the First Import of Chemicals and the Import/Export of Toxic Chemicals, 1994; Ordinance of Dangerous Chemicals Registration, 2000; Measure of Registration and Management of Dangerous Chemicals, 2002), and 27 Criteria.

Except for these national statutes, Chinese government has signed and is implementing eight international conventions and treaties related to dangerous chemicals and pesticides: London Guidelines for the Exchange of Information on Chemicals in International Trade (1989), Convention on safety in use of chemicals at work (1990), Basel Convention on the Control of Transboundary Movements of Hazardous Wastes and their Disposal (1991), UN Agenda 21 (1992), Rotterdam Convention on the Prior Informed Consent Procedure on International Trade in Hazardous Chemicals and Pesticides (1998), International Maritime Dangerous Goods Code (2000), Stockholm Convention on Persistent Organic Pollutants (2001), International Code of Conduct on the Distribution and Use of Pesticides (2003).

\subsubsection{Demarcation of statutes}

All of these constituted statutes are playing their own roles through each procedure of pesticidal POPs management, which basically includes: registration, identification, classification, production, package, reservation, trade, import, export, transportation, use, disposal and supervision. The pesticidal POPs management related statutes were summarized and classified according to their management demarcation (STD/SEPA, 2001, 2003, 2004, 2006; DPLR/SEPA, 2005), and the results are shown in Table 4.

\subsection{Government administrative system}

Government administrative system involved in pesticidal POPs management in China, mainly includes those administrative branches that are responsible for organizing and overseeing pertinent institutes, companies and individuals to comply with these national statutes, criteria and international treaties.

It can be summarized that more than 10 administrative branches are involved in pesticidal POPs management in China (SEPA, 2000), and their basic functions are shown in Table 5. The State Environmental Protection Administration primarily responds the pollution prevention and control, environmental protection of pesticidal POPs substances. The Administration of Petroleum and Chemical Industry is mainly in charge of safe production. The Ministry of Health is responsible for identifying chemical and biological toxicity, and evaluating the health impact of pesticidal POPs during their production and use. The Ministry of Communications, the Ministry of Railway and the General Administration of Civil Aviation are responsible for 
Table 4

Statutes to respective procedures of pesticidal POPs management

\begin{tabular}{|c|c|c|c|c|c|c|c|c|c|c|c|}
\hline & Registration & Production & Storage & Import & Export & Transportation & Trade & Use & Disposal & Supervision & Total \\
\hline Criteria & 11 & 4 & 4 & 1 & & 5 & 1 & 1 & 4 & 13 & 41 \\
\hline Ordinances & 3 & 2 & 3 & 1 & 1 & 7 & 2 & 2 & & & 11 \\
\hline Regulations & 1 & 4 & 5 & 2 & 1 & 2 & 5 & 4 & 6 & & 6 \\
\hline Acts & 7 & & & & & & & & & & \\
\hline $\begin{array}{l}\text { International conventions and treaties signed by } \\
\text { China }\end{array}$ & 8 & & & & & & & & & & \\
\hline
\end{tabular}

Sources: STD/SEPA (2001, 2003, 2004, 2006); DPLR/SEPA (2005).

regulating the transportation of pesticidal POPs, and conducting transportation safety inspections relevant to these chemicals. The Ministry of Agriculture is mainly in charge of registration, safety of reservation, transportation, and use of pesticidal POPs. The Ministry of Public Security is responsible for controlling safety of pesticidal POPs, and issuing license for trade and transportation.

\section{Existing problems and suggestions on pesticidal POPs management in China}

Some of the pesticidal POPs such as DDT and $\mathrm{HCH}$ had been largely used in the late 40 years and caused serious pollution in China; therefore, their source investigation, phaseout, effective disposal and remediation would be imperative and important tasks for the implementation of the Stockholm Convention and some other signed conventions. Based on the status of pesticidal POPs management, social and economic conditions in China, a huge sum of money (4.3 billion USD) will be invested and some positive actions should be undertaken for keeping environment safety and human health from damage of pesticidal POPs (Li, 2006).

\subsection{Investigate the sources of pesticidal POPS}

Although most pesticidal POPs have been banned for use in China since 1983, considering the less sound management, incomplete historic records, and specific exemption situations by the Stockholm Convention, the pollution sources of pesticidal POPs become quite complex. For example, as for producers, besides those known enterprises, some unregistered small enterprises may also have produced pesticidal POPs or low quality products. All in all, there is less available comprehensive historical information about the production quantity, site location, stockpile, import, export, trade, consumption, waste and treatment capacity of pesticidal POPs. Since DDT and HCB are still produced as intermediates for dicofol and PCP in China, the uncertainty of closed-system production process and high remnant of POPs intermediate is unclear. Moreover, there is a lack of effective investigation and management approaches and technologies as well as funds for disposal of obsolete and waste materials, and remediation of contaminated sites. Fortunately, some of international cooperation projects such as Sino-Italian projects ("Strategy and Program for the Reduction and Phase-out of Pesticidal POPs in China") (SICPEP, 2001), has been conducted to investigate the sources of pesticidal POPs.

\subsection{Improve monitor capacity and evaluate the pollution levels and health effects}

To date, China has no systematic approach to address environmental quality criteria, discharge control criteria and maximum tolerable level in food as well as corresponding monitoring methods for POPs. And the detection instruments and skillful analyzers are also far from the requirements of POPs monitoring and control. Although there are a few researches on pesticidal POPs in China recently, most of them focused on

Table 5

Government administrative branches and their functions in pesticidal POPs management

\begin{tabular}{|c|c|c|c|c|c|c|c|c|c|c|}
\hline Government administrative branches & Registration & Production & Import & Export & Storage & Transportation & Trade & Use & Disposal & Supervision \\
\hline State Environmental Protection Administration & $\sqrt{ }$ & $\sqrt{ }$ & $\sqrt{ }$ & $\sqrt{ }$ & $\sqrt{ }$ & $\sqrt{ }$ & $\sqrt{ }$ & $\sqrt{ }$ & $\sqrt{ }$ & $\sqrt{ }$ \\
\hline Ministry of Health & & $\sqrt{ }$ & $\sqrt{ }$ & & & & $\sqrt{ }$ & $\sqrt{ }$ & & $\sqrt{ }$ \\
\hline Ministry of Agriculture & $\sqrt{ }$ & $\sqrt{ }$ & $\sqrt{ }$ & $\sqrt{ }$ & $\sqrt{ }$ & $\sqrt{ }$ & $\sqrt{ }$ & $\sqrt{ }$ & $\sqrt{ }$ & $\sqrt{ }$ \\
\hline State Economic and Trade Commission & $\sqrt{ }$ & $\sqrt{ }$ & & & $\sqrt{ }$ & $\sqrt{ }$ & $\sqrt{ }$ & $\sqrt{ }$ & $\sqrt{ }$ & $\sqrt{ }$ \\
\hline Administration of Petroleum and Chemical Industry & $\sqrt{ }$ & $\sqrt{ }$ & $\sqrt{ }$ & & $\sqrt{ }$ & & & $\sqrt{ }$ & $\sqrt{ }$ & \\
\hline Ministry of Foreign Trade and Economic Cooperation & & & $\sqrt{ }$ & $\sqrt{ }$ & & & & & & \\
\hline Ministry of Communications & & & & & $\sqrt{ }$ & $\sqrt{ }$ & & & & \\
\hline Ministry of Railway & & & & & $\sqrt{ }$ & $\sqrt{ }$ & & & & \\
\hline General Administration of Civil Aviation & & & & & $\sqrt{ }$ & $\sqrt{ }$ & & & & \\
\hline Ministry of Public Security & & $\sqrt{ }$ & & & $\sqrt{ }$ & $\sqrt{ }$ & $\sqrt{ }$ & $\sqrt{ }$ & $\sqrt{ }$ & $\sqrt{ }$ \\
\hline $\begin{array}{l}\text { General Administration of Quality Supervision } \\
\text { Inspection and Quarantine }\end{array}$ & & $\sqrt{ }$ & & & & & $\sqrt{ }$ & & & $\sqrt{ }$ \\
\hline Customs General Administration & & & $\sqrt{ }$ & $\sqrt{ }$ & & & & & & \\
\hline
\end{tabular}

Sources: SEPA (2000). 
those developed areas, such as southeast and east China. Compared with the wide land of China, the monitoring data are very limited. Of course, it is partly attributed to the lag of economic development in the western and northern China. Further researches should include monitoring of POPs process production, use, disposal, and residual level in environmental media, in biological organisms and in human bodies all over the country. Moreover, for biological organisms, the exposure pathways, risks, and measures for reducing the exposure risk should be carried out as well. Fortunately, with the help of some developed countries, some international projects such as "A toxicity study of POPs on woman and children" (SCIO/SEPA, 2006a) and "Capacity Building of POPs Analysis in China" (SCIO/SEPA, 2006b) have been carried out recently.

\subsection{Investigate the alternative product of pesticidal POPs in use}

Considering the special situations in China, DDT, chlordane, HCB and mirex are still in production and use under the exemption from Stockholm Convention. However, the potential hazards will continue to exist if the pesticidal POPs are still being produced and used, which will not likely to decrease until the economical and effective alternatives or incentives are found or provided. Furthermore, the exemption for the production and application of chlordane and mirex will terminate in 2009, for DDT will be 2014. Therefore, it is necessary to investigate and develop new alternatives within the possible capacity of China to reduce the pollution potential completely. China government has already conducted an international cooperation project with Canada government "A case study on POPs alternatives for termite control in China" (XHNA, 2006).

\subsection{Complete the management framework of pesticidal POPS in China}

Successful management and control of pesticidal POPs heavily depend on the complete legal system and sound government administrative system. Considering the current situation of China, as a priority, an effective management should be established based on scientific decision-making; and recently the life-cycle management process has been introduced into POPs management (Wang et al., 2005b). Secondly, the executive validity of the current regulations should be enforced to cease illegal production and usage. Thirdly, the existing statutes should be amended to reflect the specific issues of POPs, and all pesticidal POPs related regulations and criteria should be integrated into a cohesive and coherent whole for managing pesticidal POPs, and thereafter, a specific regulation should be constituted for POPs management. As for administrative branches, it is necessary to assign and strengthen the respective role for each POPs related branch, and to organize their cooperation on managing and supervising all procedures concerning to pesticidal POPs. In recent years, Chinese government and research institutes have taken a series of positive actions and devoted great efforts to improving the management force and research level. For example, National POPs Work Group was set up in 2000, POPs Convention Implementation Office was established within SEPA in 2003, and NIP Development Leading Group comprising of 11 pertinent Ministries/Agencies was established in 2003 in China. In addition, National Expert Team on POPs as a strong and professional technical support was established to provide technical and management proposal for NIP development, convention negotiation, program development and implementation (Zhang, 2005).

\subsection{Encourage public participation awareness}

Without public participation, any problems associated with pesticidal POPs cannot be solved satisfactorily with only government administrative branches and research institutes involved in decision-making. Therefore, the most feasible and effective approach is to promote public awareness, to conduct trainings among producers, operators, consumers, and citizens, to popularize the knowledge on environment and health issues of POPs and corresponding policies and actions, and to introduce ways and manners of public participation (Yuan, 2005). Up to now, more than six of international workshops and several national symposiums were held in China, "Actions on POPs in China" was issued, "Preliminary Plan for POPs Program in China" is updated periodically, a series of booklets, pamphlets, and foldouts for increasing awareness were designed and handed out. Moreover, "China POPs Network" (http:// www.china-pops.net/) was constructed in 2000 to promote communication and discussion, and disseminate POPs information among the public and private sectors.

\subsection{Cooperate with developed countries}

The pollution problems caused by persistent organochlorine pesticides in developing countries tend to be much more serious than those in developed countries, partly because of their technical, social and economic constraints which play important roles in management and control of pollution. However, if the local pollution cannot be controlled, it will have global effects. Therefore, international cooperation will be very necessary for developing countries. For example, Japan, USA and some other developed countries have grasped safe disposal techniques, such as incineration, and modern landfill, and effective samplepretreatment and analytical detection methods for POPs substances as well. Therefore, cooperation and communication with these developed countries will greatly promote and accelerate the risk assessment and management of pesticidal POPs in China. In the recent years, China has already built cooperation on POPs control with many countries (SEPA, 2003), such as Canada ("A case study on POPs alternatives for termite control in China", "A toxicity study of POPs on woman and children"), Italy ("Strategy and Program for the Reduction and Phase-out of Pesticidal POPs in China"), the United States ("Sino-US Workshop on Science-Based Decision MakingImplementing the Stockholm Convention on Persistent Organic Pollutants (POPs)"), Japan ("Capacity Building of POPs Analysis in China") and some other international organizations within multiple fields including source survey, analysis 
determination, alternatives development, safe disposal, and risk assessment techniques (Qin, 2004b). With these international cooperative projects, China will definitely improve management and control of its serious pollution problems in the near future.

\section{Conclusions}

During the past several decades with rapid economic development, China produced and used large quantities of persistent organochlorine pesticides for protecting agriculture and preventing infectious diseases. However, their lack of comprehensive information and effective management on production, consumption, import, export, trade, stockpile and disposal impedes their implementation of POPs program. In this study, information on potential pollution sources of pesticidal POPs in China was presented and its redundant and over-lapping functions within the existing management framework were identified. On the basis of historic and present situations of pesticidal POPs use and management, the existing problems can be grouped into five issues: unknown pollution sources, limited monitoring, incomplete management framework, lack of safe disposal and remediation infrastructure, and lack of public participation awareness. Aiming at these problems, six recommendations are proposed: investigate the pollution sources, improve monitoring level, seek alternative products that are environmentally friendly, complete management framework for achieving high level of effectiveness and efficiency, encourage public participation awareness, and strengthen international cooperation.

\section{Acknowledgements}

This study was partially supported by the 21 st Century COE Program "Environmental Risk Management for Bio-Eco Systems" of MEXS, Japan.

\section{References}

Cai DJ, Sun LJ, Ke JL, Tang GC. Technical report RP032: pesticide usage in China. Environment Canada, Canada: Ontario; 1992.

Cheng X. The pesticides production of China going to a period of higher efficient and more secure. Pesticides (in Chin) 1990;29(1):15-9.

Cheng JA. Status and strategies of termite prevention in China. Memoirs of seminar on persistent organic pollutants. Beijing: SEPA; 2001. p. 83.

Chen LG, Ran Y, Xing BS, Mai BX, He JH, Wei XG, et al. Contents and sources of polycyclic aromatic hydrocarbons and organochlorine pesticides in vegetable soils of Guangzhou, China. Chemosphere 2005;60(7):879-90.

DPLR/SEPA (Department of Policies, Laws and Regulations of State Environmental Protection Administration of China). Complete book of environmental protection laws and regulations in China (1982-2005). Beijing: China Environmental Science Press; 2005.

Fu JM, Mai BX, Sheng GY, Zhang G. Persistent organic pollutants in environment of the Pearl river delta, China: an overview. Chemosphere 2003;52:1411-22

Huang HX. Discussion on environmental contaminant and related problems caused by organochlorine pesticides. Sci Manage Pesticide 1989;2:26-9.

Igbedioh S. Minimizing environmental and health effects of agricultural pesticides in developing countries. Ambio 1991;20:219-21.

Jones KC, Voogt PD. Persistent organic pollutants (POPs): state of the science. Environ Pollut 1999;100:209-21.
Kannan K, Tanabe S, Tatsukawa R. Geographical distribution and accumulation features of organochlorine insecticide residues in fish in tropical Asia and Oceania. Environ Sci Technol 1995;29:2673-83.

Li YF. Global technical hexachlorocyclohexane usage and its contamination consequences in the environment: from 1948-1997. Sci Total Environ 1999a;232:121-58.

Li ZY. Trends and strategies of global control over persistent organic pollutants. Modern Chem Ind 1999b;7:5-8 (in Chinese).

Li FC. Get on top of POPs problem. China Daily; 2006. p. 1-2. (June 22nd).

Li YF, Bidleman TF, Barrie LA, McConnell LL. Global hexachlorocyclohexane use trends and their impact on the arctic atmospheric environment. Geophys Res Lett 1998a;25:39-41.

Li YF, Cai DJ, Singh A. Hexachlorocyclohexane use trends in China and their impact on the environment. Arch Environ Contamin Toxicol 1998b;35: 688-97.

Li YF, Cai DJ, Singh A. Historical DDT use trends in China and usage data gridding with $1 / 4^{\circ}$ by $1 / 6^{\circ}$ longitude/latitude resolution. Adv Environ Res 1998c;2(4):497-506.

Loganathan BG, Kannan K. Global organochlorine contamination trends: an overview. Ambio 1994;23(3):187-91.

Loganathan BG, Tanabe S, Goto M, Tatsukawa R. Temporal trends of organochlorine residues in lizard goby, Rhinogobius flumineus, from the river Nagaragawa, Japan. Environ Pollut 1989;62:237-51.

NBSC ( National Bureau of Statistics of China ). China Statistical Yearbook 2005. Beijing: China Statistics Press; 2005.

PANNA (Pesticide Action Network North America) Outlook. India to ban agricultural use of DDT. San Francisco: Pesticide action network north America regional chapter; 1990.

Qin C. 5 POPs still produced and used in country. China Daily; 2004a. p. 2. (Nov 11st).

Qin JZ. Nations partner to reduce pollutants. China Daily; 2004b. p. 2. (July 9th).

Qiu XH, Zhu T, Yao B, Hu JX, Hu SW. Contribution of dicofol to the current DDT pollution in China. Environ Sci Technol 2005;39:4385-90.

Rapaport RA, Eisenreich SJ. Historical atmospheric inputs of high molecular weight chlorinated hydrocarbons to eastern North America. Environ Sci Technol 1988;22:931-41

SCIO/SEPA (Stockholm Convention Implementation Office of State Environmental Protection Administration). Sino-Canada cooperation project: a toxicity study of POPs on woman and children; 2006a (http://www.chinapops.org $/$ popsweb/news.do?todo=view and id=764).

SCIO/SEPA (Stockholm Convention Implementation Office of State Environmental Protection Administration). Sino-Japan cooperation project: capacity building of POPs analysis in China; 2006b (http://www.china-pops.org/ popsweb/news.do?todo=view and id=772).

SEPA (State Environmental Protection Administration). National profile for sound environmental management of chemicals (in Chinese). Beijing: State Environment Protection Adminstration, China; 2000.

SEPA (State Environmental Protection Administration). List of international cooperative projects on implementing the Stockholm Convention on POPs. Beijing: State Environment Protection Adminstration, China; 2003 (http:// www.sepa.gov.cn/inte/lydt/200301/t20030122_84338.htm)(Jan 22nd).

SEPA (State Environmental Protection Administration). Report on the state of the environment in China, 2004. Beijing: State Envrionment Protection Agency, China; 2005

SICPEP (Sino-Italian Cooperation Programme for Environmental Protection). Sino-Italian cooperation project: establishment of strategy and program on reduction and phase-out of pesticidal POPs in China; 2001 (http://www. sinoitaenvironment.org/ReadNewsex1.asp?NewsID=1888).

STD/SEPA (Science and Technology Department of State Environmental Protection Administration). Newest compilation of environmental protection standards in China (1978-2000). Beijing: China Environmental Science Press; 2001.

STD/SEPA (Science and Technology Department of State Environmental Protection Administration). Compilation of environmental protection standards in China (2001-2002). Beijing: China Environmental Science Press; 2003.

STD/SEPA (Science and Technology Department of State Environmental Protection Administration). Compilation of environmental protection 
standards in China (2003-2004). Beijing: China Environmental Science Press; 2004.

STD/SEPA (Science and Technology Department of State Environmental Protection Administration). Compilation of environmental protection standards in China (2004-2006. Beijing: China Environmental Science Press; 2006.

Tanabe S. Fate of toxic chemicals in the tropics. Mar Pollut Bull 1991;22: 259-60.

Tatsukawa R, Wakimoto T, Ogawa T. BHC residues in the environment. In: Matsumara F, Boush CM, Misato T, editors. Environmental toxicology of pesticides. New York, NY: Academic Press; 1972. p. 229-38.

UNEP (United Nations Environment Programme). Central and North East Asia regional report, regionally based assessment of PTS, UNEP/GEF; 2002.

UNIDO (United Nations Industrial Development Organization). Building the capacity of the People's Republic of China to implement the Stockholm Convention on POPs and develop a National Implementation Plan, GEF1412, UNIDO/GEF/WB; 2003.

USEPA (US Environmental Protection Agency). DDT: A review of scientific and economic aspects of the decision to ban its use as a pesticide. Washington DC: EPA 540/1-75-022; 1975.

USEPA (US Environmental Protection Agency). Lindane position document 2/3. Report of the US Environmental Protection Agency, 540/9-87-153, Washington DC; 1980.

Voldner EC, Li YF. Global usage of selected persistent organochlorines. Sci Total Environ 1995;160/161:201-10.
Wang TY, Lv YL, Zhang H, Shi YJ. Contamination of persistent organic pollutants and relevant management in China. Environ Int 2005a;31(6) $813-21$.

Wang XT, Tang XY, Hu JX. Current researches and trends of life cycle assessment on pesticide-kind POPs. Environ Sci Trends 2005b;1:60-3.

Wania F, Mackay D. Tracking the distribution of persistent organic pollutants. Environ Sci Technol 1996;30:390A-6A.

WB (World Bank). Demonstration of alternatives to chlordane and mirex in termite control, GEF-2359, Document of World Bank; 2005.

Wong MH, Choi K, Grosheva E, Sakai S, Shibata Y, Suzuki N, Wang J, Zhou H, Leung A. Central and North East Asia regional report-Regionally based assessment of persistent toxic substances. UNEP/GEF; 2002.

Xia CG, Dai ZR. The termitic damage and the usage of termitic insecticide in China. Agric Sci Manage 2001;22:16-7 (Supplement).

XHNA (Xinhua News Agency). WB helps China to phase out pollutants. Xinhua News Agency; 2006 (July 4th).

Yuan W. Education urged on persistent pollutants. China Daily; 2005. p. 3. (Nov 11st)

Zhang LJ. China is keen to prevent and reduce POPs. China Daily; 2005. p. 4. (Nov 12nd).

Zhang ZM. The development of Chinese pesticide industry. Pesticides 1996;35(1):12-4. 